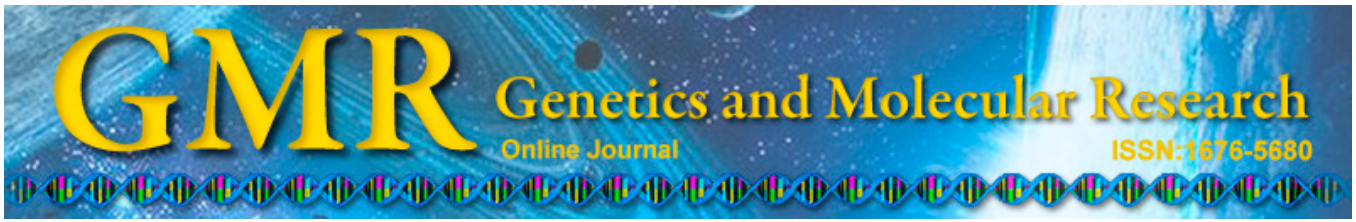

\title{
Gene expression of antioxidant enzymes and coffee seed quality during pre- and post- physiological maturity
}

\author{
F.C. Santos ${ }^{1}$, F. Caixeta ${ }^{1}$, A.C.S. Clemente ${ }^{1}$, E.V. Pinho ${ }^{1}$ and \\ S.D.V.F. Rosa ${ }^{2}$ \\ ${ }^{1}$ Laboratório Central de Análise de Sementes, Departamento de Agricultura, \\ Universidade Federal de Lavras, Lavras, MG, Brasil \\ ${ }^{2}$ Embrapa Café, Brasília, DF, Brasil \\ Corresponding author: S.D.V.F. Rosa \\ E-mail: sttela.rosa@embrapa.br
}

Genet. Mol. Res. 13 (4): 10983-10993 (2014)

Received November 25, 2014

Accepted July 30, 2014

Published December 19, 2014

DOI http://dx.doi.org/10.4238/2014.December.19.21

\begin{abstract}
Seeds collected at different maturation stages vary in physiological quality and patterns of protective antioxidant systems against deterioration. In this study we investigated the expression of genes that codify catalase (CAT), dismutase superoxide (SOD), and polyphenol oxidase (PPO) during the pre- and post-physiological maturation phases in whole seeds and in endosperms and embryos extracted from the seeds. Coffea arabica L. berries were collected at the green, yellowish-green, cherry, over-ripe, and dry stages, and the seeds were examined physiologically. The transcription levels of the genes were quantified by quantitative real-time polymerase chain reaction using coffee-specific primers. The highest level of $S O D$ expression was observed in the endosperm at the cherry and over-ripe stages; in addition, these seeds presented the greatest physiological quality (assessed via germination test). The highest CAT3 transcript expression was observed at the green stage in whole seeds, and at the green and over-ripe stages in the embryos and endosperms.
\end{abstract}


High expression of the PPO transcript was observed at the green and yellowish-green stages in whole seeds. In embryos and endosperms, peak expression of the PPO transcript was observed at the green stage; subsequently, peaks at the cherry and over-ripe stages were observed. We concluded that the expression patterns of the SOD and CAT3 transcripts were similar at the more advanced maturation stages, which corresponded to enhanced physiological seed quality. High expression of the PPO transcript at the over-ripe stage, also observed in the embryos and endosperms at the cherry stage, coincided with the highest physiological seed quality.

Key words: Catalase; Superoxide dismutase; Polyphenol oxidase

\section{INTRODUCTION}

Coffee is one of the main Brazilian agricultural export products and, in economic terms, it is considered one of the most important food crops worldwide; it is second among the global commodities after petroleum (Esquivel and Jiménez, 2012). In spite of its economic importance in Brazil, little is known about the factors that influence flowering, and berry and seed formation of the coffee tree. Therefore, it is important to elucidate the underlying causes affecting coffee seed quality during the final phases of the berry maturation process to obtain better quality seeds that will result in more vigorous seedlings and, consequently, an increase in the final crop yield. In coffee production, the berry development and maturation processes last for 6-8 months, a period during which there are a series of metabolic events that affect physical, biochemical, and physiological characteristics, as shown by changes in composition, coloring, texture, and more. Senescence, however, is characterized by a series of events that causes cell death (De Castro et al., 2005).

Deterioration in seeds is a process determined by a series of physiological, biochemical, physical, and psychological alterations that begin at physiological maturity and progress thereafter, which lead to a decrease in quality and culminate in seed death (Marcos Filho, 2005). Loss of seed viability as deterioration progresses may be related to biochemical alterations that negatively affect metabolic activities (Pimenta et al., 2004; Borém et al., 2008).

With the release of the expressed sequence tags (ESTs) in coffee in the databanks by Lin et al. (2005) and Poncet et al. (2006), studies on gene expression have increased and aim to understand the molecular mechanisms that act during coffee seed formation. Studies at these levels present great potential and contribute to the development of coffee production. It is essential that researchers consider the precise positioning of an event throughout the developmental process.

In coffee, the concentrations of antioxidant enzymes vary in accordance with the different tissues (Brandão Junior et al., 2002; Lupetti et al., 2003; Lima et al., 2004). Reduced activity of the enzymes is related to a loss of seed viability (Hoekstra et al., 1997) caused by an increase in lipid peroxidation and free radical accumulation during dehydration, the consequential reduction in berry quality (Brandão Junior et al., 1999, 2002; Lima et al., 2004), and loss of biological activity in seeds that are sensitive to desiccation (Nkang et al., 2000; Alscher et al., 2002). 
Reduction in the activity of peroxide removing enzymes may contribute to the deterioration process because the seeds become more sensitive to the effects of reactive oxygen and free radicals (McDonald, 1999; Beltrão and Oliveira, 2007). Enzymes, including catalase (CAT) and superoxide dismutase (SOD), are protective systems that take part in removing reactive oxygen species (ROS) (Kibinza et al., 2011). The polyphenol oxidase (PPO) enzyme in coffee berries is bonded to the cell membranes and, in the presence of oxygen, causes oxidation of certain compounds (Lupetti et al., 2003) such as quinones (Pimenta et al., 2004).

Characterization of the endogenous enzymatic antioxidant system may contribute to the biological characterization of the coffee maturation process because the conditions under which the maturation process advances influence berry quality, phenol content, and, consequently, seed quality (Brennan and Frenkel, 1977).

Thus, the objective of the present study was to investigate the expression of the CAT3, SOD, and PPO enzyme genes at different pre-and post-physiological maturity stages, and in various seed tissues of Coffea arabica $\mathrm{L}$.

\section{MATERIAL AND METHODS}

Coffee berries from the Rubi cultivar were collected in the experimental field at the Universidade Federal de Lavras (UFLA) at the green, yellowish-green, cherry, over-ripe, and dry development stages. Each stage occurred at different points in time, which were defined as the plants presenting most of the berries in a particular developmental stage at a given point in time; plants were randomly selected for sampling. The berries were collected from the middle branches of the trees and the central parts of the branches. After collection, berries at each stage were selected to standardize the maturation stage in accordance with the phenological scale proposed by Pezzopane et al. (2003). The water content was determined in the berries at each stage by the acclimatized ambient method at $105^{\circ} \mathrm{C}$ for $24 \mathrm{~h}$ (Brasil, 2009).

The seeds were removed from the berries by hand, and the endosperms were mechanically extracted. Subsequently, the seeds were subjected to a germination test. Whole seeds were used for the gene expression studies in addition to the separated embryos and endosperms. The extracted plant materials were frozen in liquid nitrogen and stored in a freezer at $-80^{\circ} \mathrm{C}$ until the analyses were conducted.

The germination test was carried out with four 50 seed replications for each phenological stage. The seeds were placed on germination paper, moistened with a quantity of water equivalent to 2.5 times the weight of the dry substrate, and maintained in a germinator at $30^{\circ} \mathrm{C}$ under light. The assessments were conducted at 15 and 30 days after sowing according to the rules for seed testing (RAS) (Brasil, 2009), and the results were expressed as percentages. At 15 days after sowing, the percentages of root protrusion and normal seedlings were assessed. Root protusion was confirmed when seedlings had white-colored radicles, normal seedlings showed visual morphological differentiation from the main root and at least 2 secondary roots. At 30 days after sowing, the percentages of normal and normal strong seedlings were assessed. A normal strong seedling was considered to present roots longer than $2.5 \mathrm{~cm}$ and the presence of at least 2 secondary roots. At 45 days after sowing, the seedlings with open cotyledon leaves were counted, and the results were expressed as percentages. 
For analysis of the results of physiological quality evaluations, a completely randomized design with 4 replications was used across 4 maturation stages (i.e., green, yellowishgreen, cherry, over-ripe, and dry). The Assistat v7.5 Beta 2010 software was used, and the mean values were compared by the Scott-Knott test at 5\% probability.

\section{Gene expression}

All the materials used to extract RNA were treated with diethylpyrocarbonate (DEPC) at $0.5 \%$ to inactivate RNases. The solutions used were prepared with distilled, autoclaved, RNase-free water. The Plant RNA Purification Reagent (Invitrogen) reagent was used to extract RNA according to the reagent manual; $500 \mu \mathrm{L}$ chilled reagent $\left(4^{\circ} \mathrm{C}\right)$ was added to each microtube containing $\sim 100 \mathrm{mg}$ squashed material. The tubes were then incubated for $5 \mathrm{~min}$ at ambient temperature and left horizontal to maximize RNA extraction. Subsequently, the material was centrifuged for 2 min at ambient temperature at 12,000 g. The supernatant was then transferred to another tube and $100 \mathrm{~mL} \mathrm{NaCl} 5 \mathrm{M}$ was added and homogenized in a vortex. Then, $300 \mu \mathrm{L}$ chloroform was added and the tubes were homogenized by inversion. To separate phases, the samples were centrifuged for $10 \mathrm{~min}$ at $4^{\circ} \mathrm{C}(12,000 \mathrm{~g})$, and the upper aqueous phase was transferred to another tube. A volume equivalent to the aqueous phase of chilled isopropanol $(\sim 400 \mu \mathrm{L})$ was added and shaken in a vortex for $5 \mathrm{~s}$. The samples were kept at ambient temperature for $10 \mathrm{~min}$, and then centrifuged for $10 \mathrm{~min}$ at $4{ }^{\circ} \mathrm{C}(12,000 \mathrm{~g})$. The supernatant was discarded, the pellet was washed with $1 \mathrm{~mL}$ chilled $75 \%$ ethanol, and the tubes were centrifuged for $1 \mathrm{~min}$ at ambient temperature $(12,000 \mathrm{~g})$. The residual liquid was removed from the tube with a pipette, and the RNA was resuspended in $20 \mu \mathrm{L}$ Milli-Q autoclaved water. The samples were stored at $-20^{\circ} \mathrm{C}$. The quantity and quality of total RNA were assessed using the NanoVue Plus Spectrophotometer (GE Healthcare Life Sciences). The integrity of the extracted samples was assessed by subjecting the RNA to electrophoresis on a $1.5 \%$ agarose gel with ethidium bromide and visualization under ultraviolet light. The image was captured by the EDAS 290 photodocumenter $\left(\operatorname{Kodak}^{\circledR}\right)$. The whole RNA was treated with DNase I (RNase free) (Ambion).

The RNA was then purified using the RNease MinElute Cleanup Kit (QIAGEN). This purification stage was carried out to ensure the removal of genomic DNA and salts resulting from the extraction that can damage the polymerase chain reaction (PCR) efficiency. A conventional PCR reaction was conducted, followed by observation on $1.5 \%$ agarose gel to detect the presence of genomic DNA contaminating the material.

The High Capacity cDNA Reverse Transcription Kit (Applied Biosystems) was used to synthesize complementary DNA (cDNA). First, the RNA was prepared at a $1-\mu \mathrm{L}$ concentration in a final volume of $10 \mu \mathrm{L}$. A mix was then prepared containing $2 \mu \mathrm{L} 10 \mathrm{X}$ enzyme buffer, $2 \mu \mathrm{L}$ RT Radom Primers 10X, $0.8 \mu \mathrm{L}$ dNTP mix $(100 \mathrm{mM}), 1 \mu \mathrm{L}$ MultiScribeTM reverse transcriptase, and water for a final volume of $10 \mu \mathrm{L}$ for each sample. Then, $10 \mu \mathrm{L}$ of this mix was added to each solution prepared from $10 \mu \mathrm{L}$ RNA at $1 \mu \mathrm{g}$. The tubes were placed in a thermocycler and programmed with 3 stages as follows: $10 \mathrm{~min}$ at $25^{\circ} \mathrm{C}$ to anneal the primers, $2 \mathrm{~h}$ at $37^{\circ} \mathrm{C}$ for the enzyme action, and $5 \mathrm{~min}$ at $85^{\circ} \mathrm{C}$ for inactivation. The samples were stored in a freezer at $-20^{\circ} \mathrm{C}$.

The cDNA was used as a template to analyze qualitative gene expression using the ABI PRISM 7500 Real-Time PCR (Applied Biosystems) and SYBR Green detection system.

Little is known about the genes responsible for the coffee seed maturation process; 
therefore, EST searches were conducted with previously identified coffee sequences and sequences from other species deposited into the National Center for Biotechnology Information (NCBI) database. The sequences were obtained from a contig sequence bank from the Coffee Genome Project. The primers were designed using the Primer Express 4.1 software (Table 1). First, an absolute quantification assay was conducted; the standard curve, primer efficiency, and best dilution were determined for the samples. The cDNA was diluted at 1:5, 1:25, 1:125, $1: 625$, and $1: 325$.

Table 1. Specific primers used in the real-time PCR reactions to quantify gene expression of the anti-oxidative process at different coffee berry maturation stages.

\begin{tabular}{lll}
\hline Gene & Forward $\left(5^{\prime} \rightarrow 3^{\prime}\right)$ & Reverse $\left(5^{\prime} \rightarrow 3^{\prime}\right)$ \\
\hline CAT & TGACTGCCACACGATCATCTTC & CGGGAGGCAGTGGGAAA \\
SOD & GCATGGCTCTTCGAACTCTAGTC & GCCGCGCAGCTGTTG \\
PPO & CAAGGCGGTCGAGCTCAT & TGAACATTTGCTTGTTGGGTAAA \\
UBQ & CGCTGACTACAATATCCAAAAGGA & CTGCATTCCACCCCTCAGA \\
$14-3-3$ protein & TGTGCTCTTTAGCTTCCAAACG & CTTCACGAGACATATTGTCTTACTCAAA \\
\hline
\end{tabular}

After determining the 1:5 dilution and $94-97 \%$ primer efficiency, the relative expression assay was carried out by the comparative CT method with 3 replications for each sample, including negative and endogenous controls. The expressions of the 14-3-3, ubiquitin, CAT3, $S O D$, and $P P O$ enzyme genes were analyzed.

The heat conditions were $2 \mathrm{~min}$ at $50^{\circ} \mathrm{C}, 10 \mathrm{~min}$ at $95^{\circ} \mathrm{C}$, followed by forty 15 -s cycles at $95^{\circ} \mathrm{C}$ and $1 \mathrm{~min}$ at $60^{\circ} \mathrm{C}$, finalized with $1 \mathrm{~s}$ at $95^{\circ} \mathrm{C}$. The data were analyzed using the 7500 Real-Time PCR System v2.0.1 software (Applied Biosystems) in the Central Laboratory of Seed Analysis/Plant Pathology/UFLA. Each reaction was conducted with $2 \mu \mathrm{L}$ cDNA, 10 $\mu \mathrm{M}$ each primer, and 7.5 $\mu \mathrm{L}$ SYBR ${ }^{\circledR}$ Green PCR Master Mix (Applied Biosystems) to a final volume of $15 \mu \mathrm{L}$ for each sample.

To calculate the expression, each sample was first normalized with the endogenous controls 14-3-3 and ubiquitin and the relative quantification was obtained using the equation in the Figure 1. The threshold was defined automatically.

$$
\begin{aligned}
& \Delta \mathbf{C t}=\mathbf{C t}{ }_{(\mathrm{TG})}-\mathbf{C t} \mathbf{}_{(\mathrm{RGM})} \\
& \Delta \Delta \mathbf{C t}=\Delta \mathbf{C t}-\Delta \mathbf{C t} \text { (Control) } \\
& \text { Ration }=\mathbf{2}^{-\Delta \Delta \mathrm{Ct}} \\
& \begin{array}{l}
\text { Target genes (TG) } \\
\text { Reference gene mean (RGM) }
\end{array}
\end{aligned}
$$

Figure 1. Equation to calculate relative quantification.

\section{RESULTS}

The assessment of the physiological quality showed that for the seeds extracted from berries collected at the green and dry stages, the physiological potential was inferior to that of seeds at the cherry and over-ripe stages for all variables analyzed in the germination test (Table 2). There were no significant differences between the cherry and over-ripe stages and they had similar physiological qualities. The seed water content decreased from 69.94 to $23.06 \%$ as the berries were collected from the green to dry stage. 
Figure 2 shows $S O D$ gene expression in coffee seeds at the green, yellowish-green, cherry, over-ripe, and dry stages in whole seeds and different parts of the seeds (i.e., embryo and endosperm). Analysis of the SOD transcripts (Figure 2) in the coffee seeds showed greater expression at the over-ripe stage in whole seeds, embryos, and endosperms. The greatest $S O D$ expression was observed in endosperms at the cherry and over-ripe stages; at these stages, the seeds presented the highest physiological qualities assessed by the germination test (Table 2). High expression of the transcript in seed embryos was also observed at the green and dry stages. Comparison of the physiological quality of the seeds at these stages showed that they presented low physiological quality.

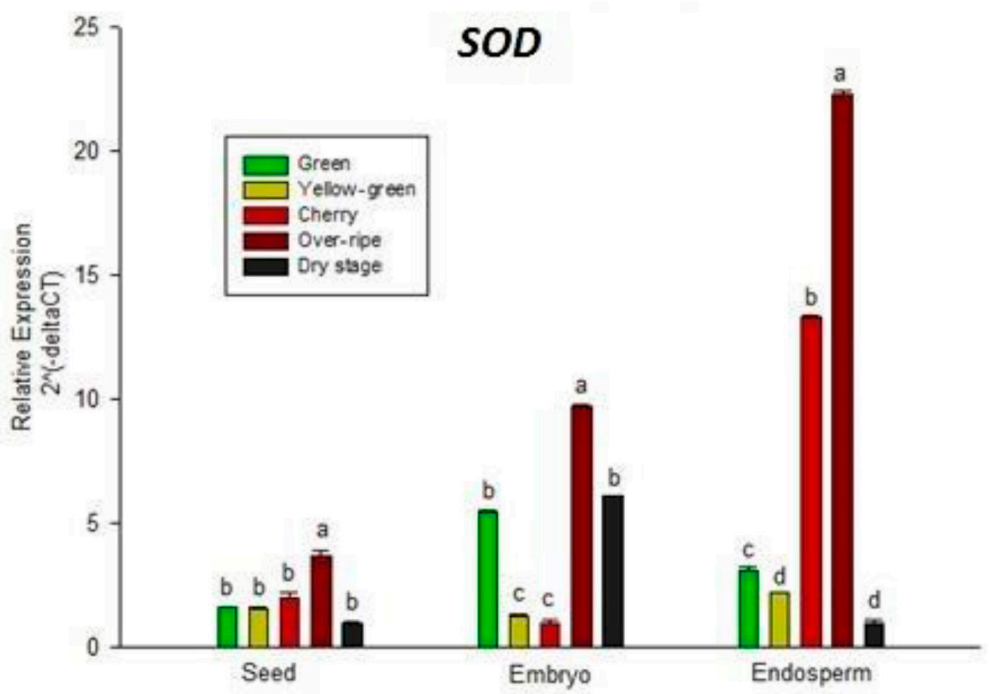

Figure 2. Quantification of superoxide dismutase $(S O D)$ gene expression in separated parts and whole coffee seeds obtained from berries collected at different maturation stages.

Table 2. Water content, mean percentage of root protrusion, normal seedlings, normal strong seedlings, and opened cotyledon of coffee seeds collected at different maturation stages of the berry.

\begin{tabular}{lccccc}
\hline Maturation stage & Water content (\%) & Radical protrusion (\%) & Normal seedlings (\%) & Normal strong seedlings (\%) & Opened cotyledon \\
\hline Green & 69.94 & $1.00^{\mathrm{D}}$ & $1.00^{\mathrm{D}}$ & $1.00^{\mathrm{D}}$ & $0.00^{\mathrm{E}}$ \\
Yellowish-green & 66.28 & $42.00^{\mathrm{C}}$ & $76.00^{\mathrm{B}}$ & $63.33^{\mathrm{B}}$ & $32.33^{\mathrm{C}}$ \\
Cherry & 68.51 & $89.00^{\mathrm{A}}$ & $82.87^{\mathrm{A}}$ & $88.00^{\mathrm{A}}$ & $58.34^{\mathrm{A}}$ \\
Over-ripe & 49.90 & $89.67^{\mathrm{A}}$ & $86.75^{\mathrm{A}}$ & $82.33^{\mathrm{A}}$ & $42.33^{\mathrm{B}}$ \\
Dry stages & 23.06 & $66.34^{\mathrm{B}}$ & $27.00^{\mathrm{C}}$ & $10.34^{\mathrm{C}}$ & $11.34^{\mathrm{D}}$ \\
\hline
\end{tabular}

Means followed by the same superscript letter in the column do not differ significantly at the level of $5 \%$ by the Scott-Knott test.

Figure 3 shows the expression of the enzyme CAT3 gene in different parts of the coffee seeds at the different stages analyzed. The highest CAT3 transcript expression was observed at the green stage in whole seeds and the green and over-ripe stages in embryos and endosperms. The lowest CAT3 expression was observed at the dry stage in the whole seeds and separated embryos and endosperms. The lowest physiological potential also occurred at this stage, confirmed by the results of the germination and seed vigor tests (Table 2). 


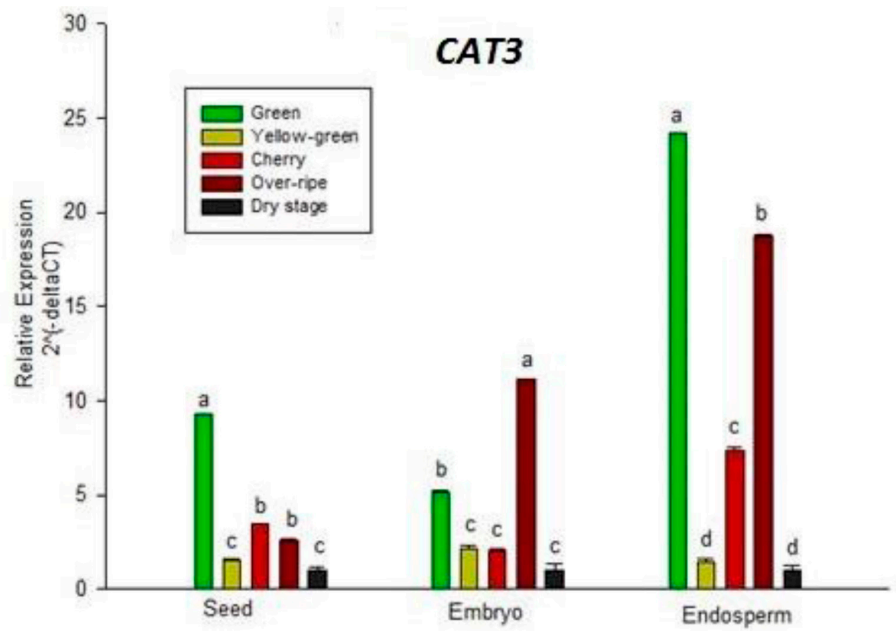

Figure 3. Quantification of catalase 3 (CAT3) gene expression in separated parts and whole coffee seeds obtained from berries collected at different maturation stages.

Figure 4 shows $P P O$ gene expression in the separated parts and whole coffee seeds at the different stages. High PPO transcript expression was observed at the green and yellowishgreen stages in whole seeds. The expression peak of the PPO transcript was also observed in embryos and endosperms at the early stage of berry maturation (green stage); subsequently, there was a peak at the intermediate cherry and over-ripe stages.

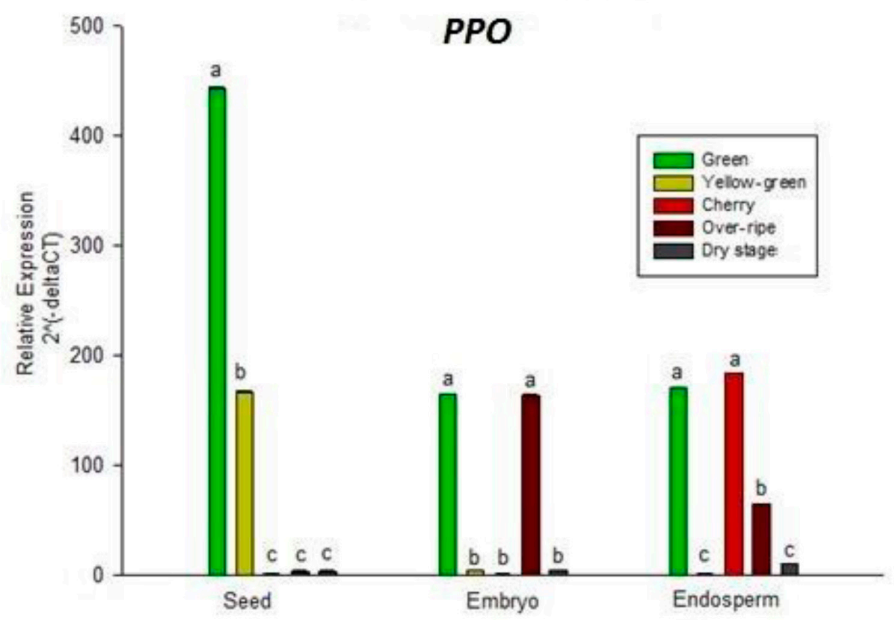

Figure 4. Quantification of polyphenol oxidase $(P P O)$ gene expression in separated parts and whole coffee seeds obtained from berries collected at different maturation stages.

\section{DISCUSSION}

Coffee berries are traditionally harvested at the cherry stage to obtain seeds for seedling production because it is understood that at this stage the seeds are physiologically mature and present maximum physiological quality. Various processes occur during seed maturation, 
such as an increase in water content and ABA levels, desiccation tolerance, and primary dormancy establishment (Holdsworth et al., 2008). The maturation phase is classically associated with a progressive decline in the base metabolism, a decrease in the hydration level of the seed, and acquisition of new competencies such as desiccation tolerance (Holdsworth et al., 2008). Seed maturation involves regulating events that integrate genetic attributes, and metabolic and hormonal signs in order to induce dormancy, a state of rest, that allows the seeds to survive in an environment (Ventura et al., 2012).

In the present research, differences in the expression patterns were observed in all the genes investigated in whole coffee seeds and the separated parts during the different maturation phases of the coffee berries. Genes associated with embryo development ( $G N, S C R$, $S T M, A R F$, and $A S N 1)$ and the start of germination (ABA3 and CAT3) showed expression at all development stages of the coffee seed, and there were no notable differences in transcript accumulation. All of the results presented herein illustrate the complexity of regulation during seed maturation.

According to Gutierrez et al. (2007), the system of superior plants is divided into 2 phases, including embryo and endosperm development, and seed maturation. Most of the genes assessed showed differences in expression throughout the maturation phases of the berries. However, in most cases, there were no significant differences among the cultivars with regard to their transcript accumulation profiles.

According to José et al. (2009), since it is expected that the selected genes were expressed exclusively in the embryos, the use of whole seeds for RNA extraction may have resulted in considerable dilution of embryonic RNA. The embryo volume is estimated at 1/40 in the whole seeds.

Water loss is known to occur during seed development and storage (Priestley, 1986; Hendry, 1993; Pammenter and Berjak, 1999; McDonald, 1999) and consequently, loss of membrane function and metabolic disturbances can be observed. This metabolic disorder caused by seed drying is accompanied by the accumulation of various ROS that can trigger innumerable deleterious oxidative processes, leading to rupture and degenerative alterations (Leprince et al., 1993; Smirnoff, 1993). Therefore, protection against oxidative processes may be one of the main determinants of seed longevity, and there are reports that antioxidant systems (e.g., SOD) play an important role in acquiring desiccation tolerance (Lee et al., 2010). This may explain the high expression of the transcripts at the later maturation stages of the berries where, in addition to reduction in water content, there was an increase in the activity and/or synthesis of enzymes of the antioxidant systems.

Montavon et al. (2007) observed high CAT3 activity at the green, cherry, and dry development stages. Montavon and Bortlik (2004) detected an increase in CAT activity with the advancement of the coffee seed maturation process. The expression levels of the SOD (Figure 2) and CAT3 (Figure 3) transcripts were similar at the more advanced maturation stages. According to Kibinza et al. (2011), among the carrier enzymes that participate in ROS removal, SOD removes superoxide $\left(\mathrm{O}_{2}{ }^{-}\right)$, thus converting it to hydrogen peroxide $\left(\mathrm{H}_{2} \mathrm{O}_{2}\right)$, which, in turn, can be decomposed by CAT to produce oxygen and water. $\mathrm{H}_{2} \mathrm{O}_{2}$ is largely responsible for oxidative stress and may contribute to regulation of the coffee berry maturation process (Brennan and Frenkel, 1977). Park et al. (2006) stated that in plants, CAT is considered a primary enzymatic defense against oxidative stress induced by senescence, chilling, stress, osmotic dehydration, wounding, ozone, paraquat, and heavy metals. 
Mazzafera and Robinson (2000) observed high PPO activity during endosperm development. According to Resende (2006), the PPO enzyme is detected in several parts of coffee seeds and bond to cell membranes. Eskin (1990) reported that the enzyme is intracellular, located mainly in the chloroplast membrane, and participates in the processes of respiration and resistance to infection by synthesis of certain plant constituents such as flavonoids and quinones. As observed in the present research, there was high PPO transcript expression at the green stage in the whole and separate parts of coffee seeds. In the green stage, there was a high water content and high metabolic and respiratory activity; thus, high PPO activity is assumed.

High PPO transcript expression in the embryos at the over-ripe stage and endosperms at the cherry stage coincided with high physiological quality of the coffee seeds at these stages. Lima (2005) observed an increase in PPO enzyme activity in seeds that presented lower values of electric conductivity and better physiological quality in the germination, seedling emergence, and emergence speed index tests. $P P O$ gene expression during climacteric and nonclimacteric fruit development has been widely investigated. In addition to contributing to our understanding of the subjacent molecular aspects of berry development, knowledge of the genetic control of these processes is important for supplying new tools to select cultivars with enhanced agronomic characteristics such as uniform and controlled maturation and defined seed chemical composition.

Quantification of the expression of a marker gene in a determined berry sample will help to efficiently establish the maturation stages of these berries. Together with post-harvest processing, this identification may contribute to the assessment of coffee seed development.

Characterization of the gene expression profiles during phenological changes that occur in seed development could allow identification of genes that indicate seed quality. Considerable advances have been made in understanding the morphology, anatomy, physiology, and molecular aspects of coffee seeds during development, germination, and storage. However, the crucial events during coffee berry and seed development, and maturation still need to be elucidated.

\section{CONCLUSION}

SOD and CAT3 transcript expression levels were similar during the more advanced stages of berry maturation and exhibited a correlation with superior physiological quality of the seeds.

High expression of the PPO transcript in the embryos of coffee seeds collected at the over-ripe stage and the endosperms at the cherry stage coincided with high physiological quality of seeds.

\section{ACKNOWLEDGMENTS}

Research supported by Empresa Brasileira de Pesquisa Agropecuária (EMBRAPA) and Coordenação de Aperfeiçoamento de Pessoal de Nível Superior (CAPES).

\section{REFERENCES}

Alscher RG, Erturk N and Heath LS (2002). Role of superoxide dismutases (SODs) in controlling oxidative stress in plants. J. Exp. Bot. 53: 1331-1341.

Beltrão NEM and Oliveira MIP (2007). Biossíntese e Degradação de Lipídios, Carboidratos e Proteínas em Oleaginosas. 
Embrapa Algodão, Campina Grande.

Borém FM, Coradi PC, Saath R and Oliveira JA (2008). Qualidade do café natural e despolpado após a secagem em terreiro e com altas temperaturas. Ciência Agrotec. 32: 1609-1615.

Brandão Junior DS, Carvalho MLM and Vieira MGGC (1999). Variações eletroforéticas de proteínas e isoenzimas relativas à deterioração de sementes de milho envelhecidas artificialmente. Rev. Bras. Sem. 21: 114-121.

Brandão Junior DS, Vieira MGGC and Hilhorst HWM (2002). Aquisição da tolerância à dessecação nos diferentes estádios de desenvolvimento de sementes de cafeeiro (Coffea arabica L.). Cienc. Agrotechnol. 26: 673-681.

Brasil. (Ministério da Agricultura e Reforma Agrária) (2009). Regras para Análise de Sementes. Mapa/ACS, Brasília.

Brennan T and Frenkel C (1977). Involvement of hydrogen peroxide in the regulation of senescence in pear. Plant Physiol. 59: 411-416.

De Castro RD, Estanislau WT, Carvalho MLM and Hilhorst HWM (2005). Functional Development and Maturation of Coffee (Coffea arabica) Fruits and Seeds. Proceedings of the 20th International Scientific Colloquium on Coffee, Bangalore, 619-635.

Eskin NAM (1990). Biochemistry of Food Spoloilog: Enzymatic Browing. In: Biochemistry of Food. 2nd edn. Academic Press, San Diego, 401-427.

Esquivel P and Jiménez VM (2012). Functional properties of coffee and coffee by-products. Food Res. Int. 46: 488-495.

Gutierrez L, Van Wuytswinkel O, Castelain M and Bellini C (2007). Combined networks regulating seed maturation. Trends Plant Sci. 12: 294-300.

Hendry GA (1993). Oxygen, free radical processes and seed longevity. Seed Sci. Res. 3: 141-153.

Hoekstra FA, Wolkers WF, Buitink J and Golovina EA (1997). Desiccation tolerance and long term structural stability. Curr. Plant Sci. Biotechnol. Agric. 30: 1-12.

Holdsworth MJ, Bentsink L and Soppe WJ (2008). Molecular networks regulating Arabidopsis seed maturation, afterripening, dormancy and germination. New Phytol. 179: 33-54.

José AC, Ligterink W, Davide AC, Silva EAA, et al. (2009). Changes in gene expression during drying and imbibition of desiccation sensitive Magnolia ovata (A. St.-Hil.) spreng seeds. Rev. Bras. Sementes 31: 270-280.

Kibinza S, Bazin J, Bailly C, Farrant JM, et al. (2011). Catalase is a key enzyme in seed recovery from ageing during priming. Plant Sci. 181: 309-315.

Lee YP, Baek KH, Lee HS, Kwak SS, et al. (2010). Tobacco seeds simultaneously over-expressing Cu/Zn-superoxide dismutase and ascorbate peroxidase display enhanced seed longevity and germination rates under stress conditions. J. Exp. Bot. 61: 2499-2506.

Leprince O, Hendry GAF and Mckersie BD (1993). The mechanisms of desiccation tolerance in developing seeds. Seed Sci. Res. 3: 231-246.

Lima DM (2005). Armazenabilidade de Sementes de Coffea arabica L. e de Coffea canephora Pierre, Submetidas a Diferentes Métodos de Desmucilagem e de Secagem. Master's thesis, UFLA, Lavras.

Lima SMP, Guimarães RM, Oliveira JA and Vieira MGGC (2004). Efeitos de tempos e temperaturas de condicionamento sobre a qualidade fisiológica de sementes de cafeeiro (Coffea arabica L.) sob condições ideais e de estresse térmico. Cienc. Agrotechnol. 28: 505-514.

Lin CW, Mueller LA, Mc Carthy J and Crouzillat D (2005). Coffee and tomato share common gene repertoires as revealed by deep sequencing of seed and cherry transcripts. Theor. Appl. Genet. 112: 114-130.

Lupetti KO, Ramos LA and Fatibello-Filho O (2003). Determinação enzimática de dopamina em formulações farmacêuticas utilizando sistema de análise por injeção em fluxo com extrato bruto de abacate (Persea americana). Quim. Nova 26: $197-201$

Marcos Filho J (2005). Fisiologia de Sementes de Plantas Cultivadas. Fealq, Piracicaba.

Mazzafera P and Robinson SP (2000). Characterization of polyphenol oxidase in coffee. Phytochemistry 55: 285-296.

McDonald MB (1999). Seed deterioration: physiology, repair and assessment. Seed Sci. Technol. 27: 177-237.

Montavon P and Bortlik K (2004). Evolution of Robusta green coffee redox enzymatic activities with maturation. J. Agric. Food Chem. 52: 3590-3594.

Montavon P, Kukic KR and Bortlik K (2007). A simple method to measure effective catalase activities: optimization, validation, and application in green coffee. Anal. Biochem. 360: 207-215.

Nkang A, Omokaro D and Egbe A (2000). Effects of desiccation on the lipid peroxidation and activities of peroxidase and polyphenoloxidase in seeds of Telfairia occidentalis. Seed Sci. Technol. 28: 1-9.

Pammenter NW and Berjak P (1999). A review of recalcitrant seed physiology in relation to desiccation-tolerance mechanisms. Seed Sci. Res. 9: 13-37.

Park SJ, Huang Y and Ayoubi P (2006). Identification of expression profiles of sorghum genes in response to greenbug phloem-feeding using cDNA subtraction and microarray analysis. Planta 223: 932-947.

Pezzopane JRM, Pedro Júnior MJ, Thomaziello RA and Camargo MBP (2003). Escala para avaliação de estádios 
fenológicos do cafeeiro arábica. Bragantia 62: 499-505.

Pimenta CJ, Vilela VR and Carvalho Junior C (2004). Componentes de parede celular de grãos de frutos de café (Coffea arabica L.) submetidos a diferentes tempos à espera da secagem. Acta Sci. Agron. 26: 203-209.

Poncet V, Rondeau M, Tranchant C, Cayrel A, et al. (2006). SSR mining in coffee tree EST databases: potential use of EST-SSRs as markers for the Coffea genus. Mol. Genet. Genomics 276: 436-449.

Priestley DA (1986). Seed Ageing: Implications for Seed Storage and Persistence in Soil. Comstock Publication Association, Ithaca.

Resende ML (2006). Alterações Fisiológicas e Bioquímicas Durante a Germinação de Sementes de Café (Coffea arabica L.) CV. Rubi. Doctoral thesis, UFLA, Lavras.

Smirnoff N (1993). The role of active oxygen in the response of plants to water deficit and desiccation. New Phytol. 125: 27-58.

Ventura L, Donà M, Macovei A, Carbonera D, et al. (2012). Understanding the molecular pathways associated with seed vigor. Plant Physiol. Biochem. 60: 196-206. 